\title{
液晶/高分子複合膜のヒステリシスに及ぼす要因
}

\author{
大日本印刷侏中央研究所 進藤忠文・前田博己・安藤雅之
}

\section{A Factor Related to Hysteresis of Light Valve Using Liquid Crystal/Polymer Composite Film}

\section{Tadafumi Shindo, Hiroki Maeda,and Masayuki Ando}

Central Research Institute, Dai Nippon Printing Co., Ltd., 250-1, Wakashiba, Kashiwa, Chiba, 277-0871 Japan

\begin{abstract}
Liquid crystal/polymer composite (LCPC) films were prepared by electron beam polymerization of nematic liquid crystal and two-functional monomer (EB-LCPC) and by emulsification of nematic liquid crystal using polyvinylalcohol (PVA-LCPC). A factor related to hysteresis of these film was investigated by analyzing the dependence of transmittance and capacitance on applied voltage. EB-LCPC was smaller in the hysteresis and the applied voltage dependence of hysteresis than PVA-LCPC. It was assumed that hysteresis occurs by structure change of LCPC film due to molecular motion of its polymer matrix.
\end{abstract}

(Received 2 February, 1999 ; Accepted 23 April, 1999)

\section{1. 緒言}

高分子マリックス中にネマチック液晶を分散安定化させた 液晶/高分子複合 (Liquid Crystal/Polymer Composite, LCPC) 膜は, 電圧の印加による液晶の屈折率变化が液晶 と高分子マトリックスの屈折率差を変化させるため, 光 の散乱一透過モードに基づく新しい光バルブとして期待 され，古くから数多くの基礎的および実用的研究が行わ れてきた[1-9].

このようなLCPC膜の作製方法は, (1)液晶含浸法, (2)液 晶乳化法, (3) 液晶相分離法に大別される[11]. 液晶含浸 法は，多孔質体に液晶を充填する方法で[2]，液晶乳化法 は、液晶をポリビニルアルコール(PVA)のような保護コ ロイドで乳化分散した後, 塗布, 乾燥する力法である[2]. 液晶相分離法は, 液晶と高分子を重合 $[4,5]$, 溶媒蒸発 [6],冷却 [6]などの様々な手段で相分離させてLCPC膜を
作製するものである.特に，液晶と紫外線(UV)硬化性樹 脂の均一溶液から, UV重合によって相分離させる方法は, 寒用的な作製法として広く研究されている。

しかしながら，いずれの方法で作製きれたLCPC膜も、 電気光学 $(E O)$ 特性や構造などに特徵が認められるものの, 光バルブとして表示デバイスに用いる場合，様々な課題 を内在している，すなわち，駆動電圧が高い，透過率の 急峻性が低い,ヒステリシスを有するなどのEO特性の問 題あるいはEO特性の経時変化や温度变化などの信頼性 の問題がある $[11,12]$.そのため，作製方法の改良や材料 設計によるLCPC膜の構造制御，その構造がEO特性に及 ほす影響などに関する研究がUV重合法を中心に行われて きた[13-19].

特に, ヒステリシスは, 光透過率一印加電圧特性にお いて，昇圧時上降压時で透過垶が異なる現象で，光バル ブが電圧印加の履歴をうけることを示しており，アクテ 
イプマトリックス方式の液晶表示デバイスにおける精細 な階調表示を不可能にする。 そのため, UV重合法で作製 されたLCPC膜を中心に，その要因解明および改良が試み られた。これまで，(1)LCPC膜中の電荷[5], (2) 液晶粒子 (高分子マトリックス)の形態 $[20,21],(3)$ 液晶と高分子の 相互作用(アンカーリング) $[20,22,23]$, (4) 液晶の配列 $[20,24,25,26],(5)$ 液晶と高分子マトリックスの物性[20] が重要な要因であると指摘され，事実，ヒステリシスの 低隇に成功している。しかし、これらの要因は複雑に絡 合っており，統一された見解には至っておらず，解決 したわけではない。

ところで, 著者らは,このようなUV重合法の欠点であ る, 光開始削の使用, 長い重合時間, 低い光透過性を改 良する方法として、これまで研究してきた電子線 $(\mathrm{EB})$ 重 合技術[27-31]の活用を試みてきた.EB重合法によるLCPC 膜の作製方法の提案は古く $[32,33]$ ，その後も種々試みら れているが[34-38], EB重合法の特徴は明確にされていな い. 著者らは, EB重合法LCPC膜のEO特性に及ほす多官 能モノマーの影響を㭘討した結果, EB重合法はUV重合 法よりもモノマーの重合率が高いことを見出し、駆動電 圧の低下，急骖性の向上，および信頼性の向上に効果的 な因子を明らかにすることができた[39].

さらにその研究過程において, LCPC膜に特有な七ス テリシスが, EB重合法上液晶乳化法で類似の挙動をとる ことを見出した，EB重合法と液晶乳化法では，得られる LCPC瞙の棈造や高分子マトリックスの物性が大きく哄な るにもかかわらず，七ステリシスに類似性が認められる ことは，上述した複雑な要因を明らかにする上で着目す ベき現象である。

そこで、本研究では，EB重合法および液晶乳化法LCPC 膜のヒステリシスの要因を, 光透過率一印加電圧特性㧍 よびキャパシタンスー印加電圧特性の解析によって明ら かにしょうとした。

\section{2. 実験}

\section{1 試料}

EB重合法でLCPC膜を作製するための二官能モノマー としては,下記に示す分子構造のエポキシエステル $40 \mathrm{EM}$ (共栄社化学制製)を, 精製することなく用いた。

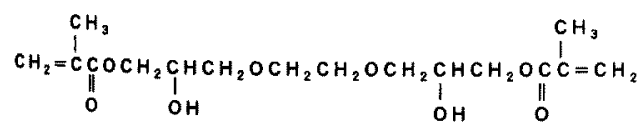

夜晶乳化法でLCPC膜を作製するための保護コロイドは, 重合度600, 战化度71.0 75.0mol\%のPVA (KP-06, 日 本合成化学工業(制製)を。このPVAを溶解する水は, 純水
(和光純薬工業淛製)をそのまま用いた。

ネマチック液晶は、E-44(Merck Ltd.製)を用いたここ の液晶の物性は, $589 \mathrm{~nm}, 20^{\circ} \mathrm{C}$ における常光屈折率 $\mathrm{n}_{0}=1.528$, 異常光屈折率 $\mathrm{n}_{\mathrm{e}}=1.790$, 屈折率異方性 $\Delta \mathrm{n}\left(=\mathrm{n}_{e}-\mathrm{n}_{0}\right)=0.262$, $20^{\circ} \mathrm{C}$ における粘度 $\gamma=47 \mathrm{cSt}, 7 \mu \mathrm{m}$ のTNセルにおける閣值

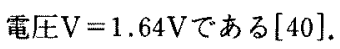

\subsection{LCPC瞙の評価用セルの作製}

LCPC膜の評洒は, EB重合法の場合, 前報[39]にした がい，次のような評価用セルを作製した，E-44/40EMが 60/40(w/w)の配合比となるように混合し, $130^{\circ} \mathrm{C} て ゙$ 加熱 することによって均一な等方性流体を得た。この流体を $130^{\circ} \mathrm{C}$ に保持されたインジウムースズ酸化物(ITO) 透明導電 膜を形成したガラス基板上に放布すると共に，スペーサ 一 $(10 \mu \mathrm{m})$ を散布した後、ITOが形成されたポリエチレン テレフタレート $(\mathrm{PET}) 7 ィ ル ム(125 \mu \mathrm{m})$ を張合わせ, $\mathrm{PET}$ フィルム側からEBを照射した。 $\mathrm{EB}$ は, 日新八イボルテー ジ侏製低エネルギー型EB照射装置EBC200-AA2を用い, 加速電圧 $180 \mathrm{kV}$, フィラメント電流 $8 \mathrm{~mA}$ の条件で, $10 \mathrm{Mrad}$ の吸収線量となるように照射した. $\mathrm{EB}$ 照射温度は, EB照 射装置のサンプル搬送基板に, 温度コントローラーを装

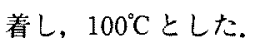

液晶乳化法の場合の評価用七ルは, $10 \mathrm{wt} \%$ の $\mathrm{KP}-06$ 水 溶液にE-44/KP-06 $=60 / 40(\mathrm{w} / \mathrm{w})$ となるように添加し， 超音波発生装置MODEL US-300T(粇製)を用いて分散し た液晶乳化液を，上述しなITO付きPETフィルム上に膜 厚 10 (mとなるように塗布, 乾燥した後, 同じTO付きPET フィルムを張合わせて作製した，乾燥条件は， $25^{\circ} \mathrm{C}, 12$ 時間とした。

\section{3 ヒステリシスの評価}

2.2で作製したLCPC膜の評価用セルの光透過率一印加 電圧特性およびキャパシタンス $\left(C_{p}\right)$ 一印加電圧特性によ ク，LCPC膜のヒステリシスを評価および解析した。印加

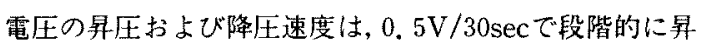
降した。

光透過率一印加電圧特性は, セル作製後直ちに, LCD5000 LCディスプレイ評洒システム(大塚電子㫼製)を用い て測定した. 北透過率の0および100\%は, ITOが形成され たガラス基板およびPETフィルムがない状態で規格化さ れ，印加電圧は， $1 \mathrm{kHz} の$ 矩形波が用いられた．光源は八 ロゲンランプを使用し，受光角 $5{ }^{\circ} に$ 検出器を装着して測 定した。

キャパシタンスー印加電圧特性は, 七ル作製後直ちに, インピーダンス測定システムMAP-1260(東陽テクニカ侏) 製)至用いて測定した。 


\section{3. 結果および考察}

\section{$3.1 \mathrm{~EB}$ 重合法および液晶乳化法LCPC膜のヒステリシス} 困 1 および 2 には, EB重合法LCPC (EB-LCPC) 膜の, 目 3 および 4 には液晶乳化法LCPC (PVA-LCPC)膜の光 透過率一印加電圧特性を昇圧時と降圧時でプロットし, それぞれ，認められるヒステリシスの最大卯加電圧 $\left(\mathrm{V}_{\max }\right)$ 依存性を示した。ヒステリシスは，昇圧時と降圧時にお ける最大透過率差 $\left(\Delta T_{H \max }\right)$ および最大電圧幅 $\left(\Delta V_{H \max }\right)$ で評価し，その結果を表 1 にまとめた，実駼装置上， $\Delta V_{H \max }$ の測定精度は0.5Vが限界であるが、 $\Delta \mathrm{T}_{\mathrm{H} \max }$ は，同一印 加電圧における透過率を精度よく測定でき，顕著な差を 見い出せた。

図1，2および表 1 から明らかなように, EB-LCPC膜の ヒステリシスは， $V_{\max }=20 \mathrm{VおよU゙50Vにおいて，それぞ}$ れ, $\Delta \mathrm{T}_{\mathrm{H} \max }=2.2$ および3.7\%を示した. $\Delta \mathrm{V}_{\text {H } \max }$ は共に $0.5 \mathrm{~V}$ 示し，両者の差は測定精度の限界を超えていた。 Maschkeら [34]は, EB重合法で作製したLCPC膜の相对 透過率 $50 \%$ におけるヒステリシス幅 $\left(V_{\mathrm{H} 50}\right)$ を評価し、 $V_{\mathrm{H} 50}$ が膜厚ならびに印加電圧の走查回数に依存することを報 告した。 その結果によれば, 最小膜厚 $13 \mu \mathrm{m}$, 最大印加電 圧 $75 \mathrm{~V} て ゙, V_{\mathrm{H} 50}$ が少なくとも $2 \mathrm{~V} に$ 達しており, 今回作製 したサンプルの膜厚が $10 \mu \mathrm{m}$ とはいえ,大幅に改良されて いる.

一方，図3，4および表1 から明らかなように, PVA-LCPC

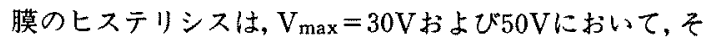
れぞれ， $\Delta \mathrm{T}_{\mathrm{H} \max }=7.3$ おび $19.5 \%, \Delta \mathrm{V}_{\mathrm{H} \max }=1.5 \mathrm{~V}$ お よび3.5Vを示し，EB-LCPC膜よりも大きいことがわか る。また，同じ液晶を使っているにもかかわらず, EB-LCPC 膜の駆動電圧よりもはるかに高い電圧を示した。これ， EB-LCPC膜が，液晶連続相に，架橋微粒子が凝集した高 分子マトリックスを充填したような構造を形成している のに対し[39], PVA-LCPC膜は, PVAマトリックスに液 晶滴が分散した構造を形成していることに起因しており [24]，これが，後述するように，液晶分子の配向速度に 影響を及ほすものと考えられる。

さらに,着目すべきことは，ヒステリシスが,EB-LCPC 膜, PVA-LCPC膜共に, $V_{\max }$ の増大にしたがって顕著に なり，その変化率が, EB-LCPC膜の方が小さいことお よび，EB-LCPC膜において，印加電圧約20Vで能和した

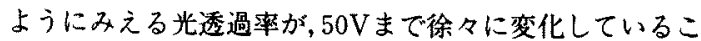
とである。

このように，EB-LCPC膜とPVA-LCPC膜は，上述し たように，構造および高分子マトリックスの物性が全く

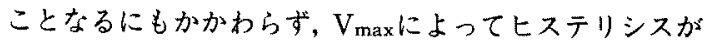
大きくなるという類似性を示したことは，ヒステリシス

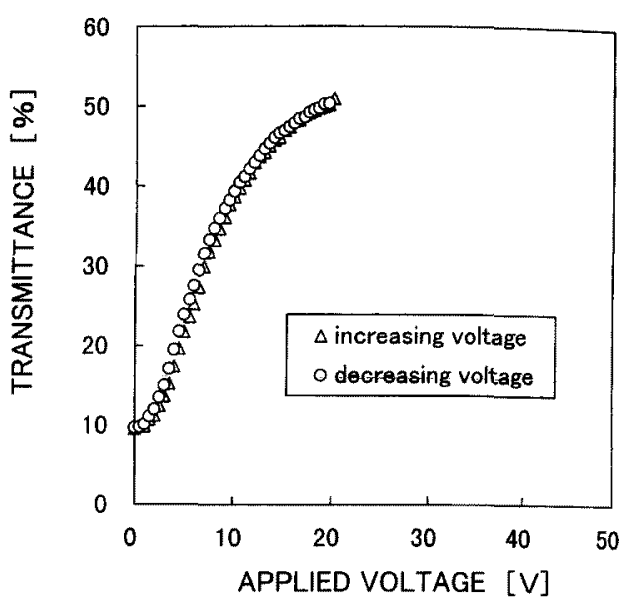

Fig. 1 Transmittance vs. applied voltage between 0 and 20 V for EB-LCPC film. Liquid crystal/monomer ratio, $\mathrm{E} \cdot 44 / 40 \mathrm{EM}=60 / 40(\mathrm{w} / \mathrm{w})$; irradiation dose, $10 \mathrm{Mrad}$; thickness of cell , $10 \mu \mathrm{m} .(\Delta)$, increasing voltage; $(\mathrm{O})$, decreasing voltage.

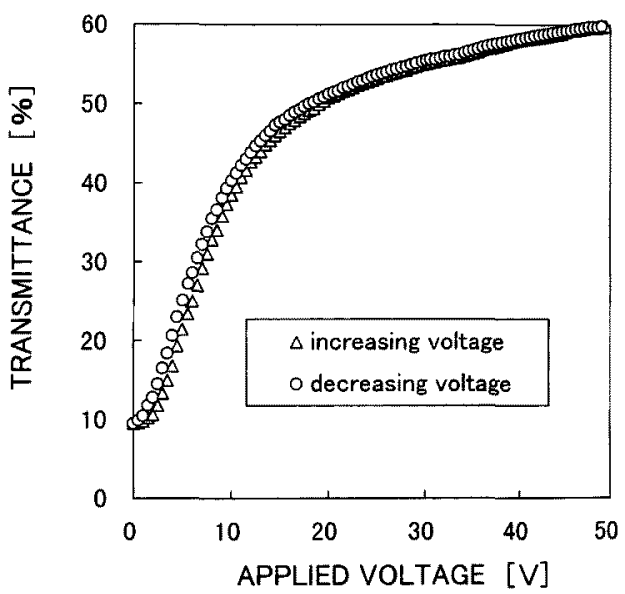

Fig. 2 Transmittance vs. applied voltage between 0 and 50 $\mathrm{V}$ for EB-LCPC film. Liquid crystal/monomer ratio, $\mathrm{E}-44 / 40 \mathrm{EM}=60 / 40(\mathrm{w} / \mathrm{w})$; irradiation dose, $10 \mathrm{Mrad}$; thickness of cell, $10 \mu \mathrm{m} .(\Delta)$, increasing voltage; $(\mathrm{O})$, decreasing voltage.

Table 1 Hysteresis of EB-LCPC and PVA-LCPC film

\begin{tabular}{cccc}
\hline Sample & Max. Applied & \multicolumn{2}{c}{ Hysteresis } \\
\cline { 3 - 4 } & Voltage (V) & $\Delta \mathrm{T}_{\text {Hmax }}(\%)$ & $\Delta \mathrm{V}_{\text {H } \max }(\mathrm{V})$ \\
\hline EB-LCPC Film & 20 & 2.2 & 0.5 \\
& 50 & 3.7 & 0.5 \\
\hline PVA-LCPC Film & 30 & 7.3 & 1.5 \\
& 50 & 19.5 & 3.5 \\
\hline
\end{tabular}




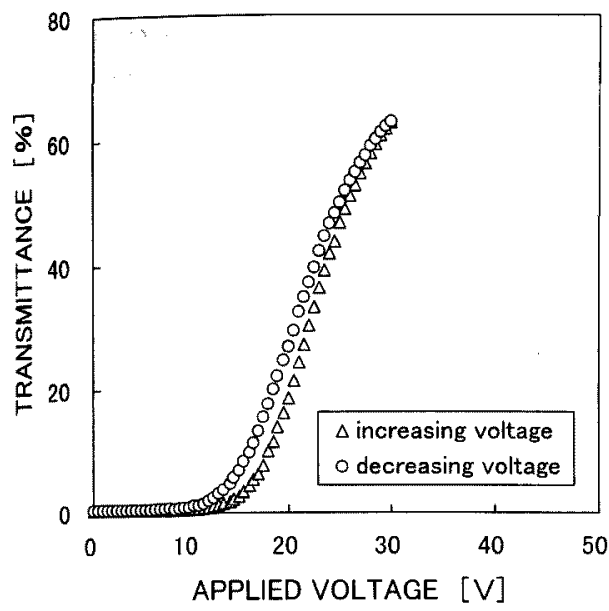

Fig. 3 Transmittance vs. applied voltage between 0 and 30 $\mathrm{V}$ for PVA-LCPC film. Liquid crystal/monomer ratio, $\mathrm{E}-44 / \mathrm{PVA}=60 / 40(\mathrm{w} / \mathrm{w})$; irradiation dose, $10 \mathrm{Mrad}$; thickness of cell, $10 \mu \mathrm{m}$. $(\Delta)$, increasing voltage; $(O)$, decreasing voltage.

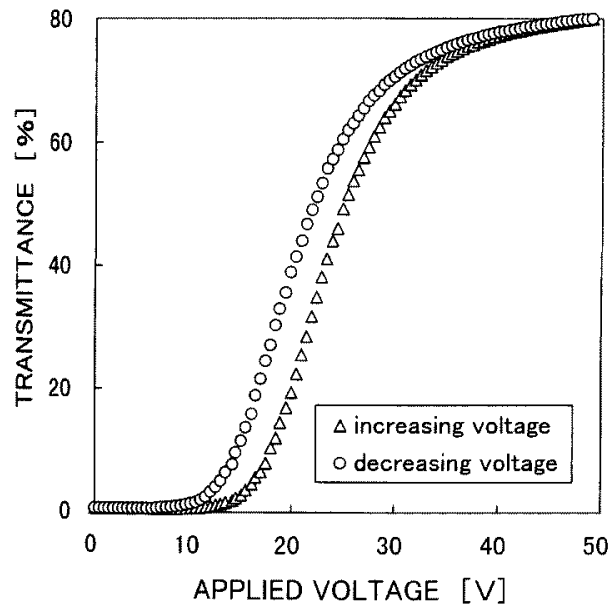

Fig. 4 Transmittance vs. applied voltage between 0 and 50 $\mathrm{V}$ for PVA-LCPC film. Liquid crystal /monomer ratio, E-44/PVA $=60 / 40(\mathrm{w} / \mathrm{w})$; irradiation dose, $10 \mathrm{Mrad}$; thickness of cell, $10 \mu \mathrm{m} .(\Delta)$, increasing voltage; $(\mathrm{O})$, decreasing voltage.

の要因に共通性があるものと予測される。ヒステリシス の測定に必要な印加電圧は, 膜厚が小さいため, 電界強 度としては, $10 \mathrm{Vで} 10 \mathrm{kV} / \mathrm{cm}$ も達しており,これがLCPC 膜の高分子マトリックスの構造に与える影響があるので はないかと考えた。

一般に、ここで用いているような二官能アクリレート
モノマーのEB重合によって得られた高分子の分子運動性 は極めて低く，また，乾燥したPVAも約100(Cのガラス 転移温度 $\left(\mathrm{T}_{\mathrm{g}}\right)$ を有している。

しかし，EB-LCPC膜は，重合率が100\%に達すること はなく，高分子マトリックス中に液晶が溶解しているこ とが報告されている[5,6]. 著者らは[39],ここで扱って いるEB-LCPC膜の重合率が60\%で, その光透過率一印加 電圧特性の経時変化を認め, 高分子マトリックス中に残 存するモノマーが液晶中に溶出されるためであると考え た一方, PVA-LCPC膜にしても，液晶がPVA中に溶解 しているものと考えられる.液晶とポリ塩化ビニル (PVC) の均一溶液から溶媒を蒸発させることによって作製され るLCPC膜では，PVCのT $\mathrm{T}_{\mathrm{g}}$ 䄪30(C低下し，PVC中に液 晶が溶解していることが確認されている[41].

このことは，液晶分子が，高分子マトリックス中で, 可塑阂として働くばかりか，電圧印加に伴う液晶分子の 配向が高分子マトリックスの変形を促す可能性があるこ とを示唆している。つまりこのような高分子マトリッ クスの分子運動性が，印加䉓圧に伴うヒステリシス変化 の類似性を明らかにするだけでなく，ヒステリシスの変 化率がEB-LCPC膜とPVA-LCPC膜で異なることや，飽 和したようにみえる光透過率が徐々に変化することと関 連があるものと推測される。ただし, EB-LCPC膜の場合 には，高分子マトリックスの分子運動によって，その残 存モノマーの液晶中への溶出が引起こされる可能性があ ク，液晶の物性変化も関与しているものと考えられる。

\subsection{LCPC膜のヒステリシスの要因}

前節において，LCPC膜のヒステリシスは，その高分子 マトリックスの分子運動性と関連があることを示した。 このことを明らかにするため, LCPC膜のキャパシタンス $\left(\mathrm{C}_{\mathrm{p}}\right)$-印加電压特性の評洒に上り検討した，一般に，一 様に液晶が配向したセルに電圧を印加した場合の解析は 確立されており，電压を印加した場合の闌值を測定する 際に，分子配向の変化はC る[42].

図 5 には，EB-LCPC膜に所定の電圧まで昇圧一降在 繰り返し, 其圧時の $\mathrm{C}_{\mathrm{p}}$ 変化を1st Scanning $(\square) \rightarrow 2$ nd Scanning $(\square) \rightarrow$ 3rd Scanning $(\mathrm{O}) \rightarrow 4$ th scanning $(\mathbf{O}) \rightarrow$ 5 th scanning $(\Delta) の$ 順に示した, 図 6 には, PVA-LCPC 膜に関する同様の測定結果を，1st Scanning $(\square) \rightarrow 2$ nd Scanning $(\square) \rightarrow$ 3rd Scanning $(O) \rightarrow 4$ th scanning $(O) \infty$ 順に示した。このような方法によって, LCPC膜に加えら れた電圧の変化に伴う, 液晶分子の配向状態に関する履 歴を観察することができる。そこで，これらの配问状態 を図 2 おび 4 の光透過率一印加電圧特性と比較考察し t. 


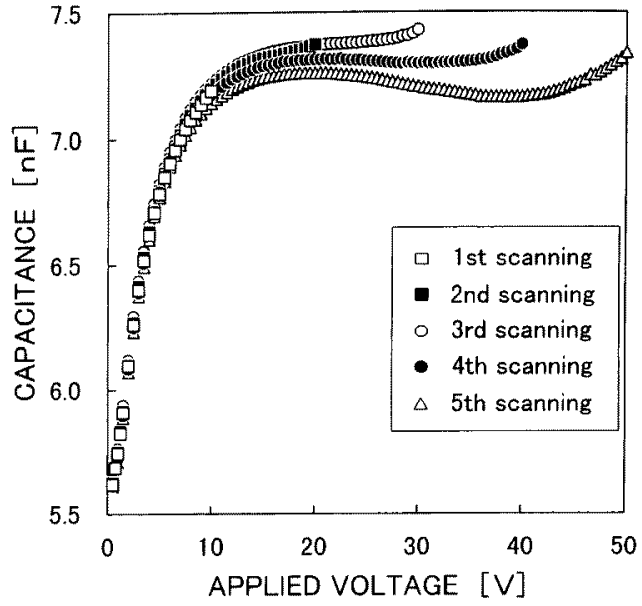

Fig. 5 Capacitance vs. applied voltage for EB-LCPC film Liquid crystal/monomer ratio, E-44/40EM $=60 / 40$ (w/w); irradiation dose, 10Mrad; thickness of cell , $10 \mu \mathrm{m}$. Scanning order: $(\square), 1 \mathrm{st} ;(\mathbb{G}), 2 \mathrm{nd} ;(\mathrm{O}), 3 \mathrm{rd}$; (O), 4th; $(\Delta), 5$ th.

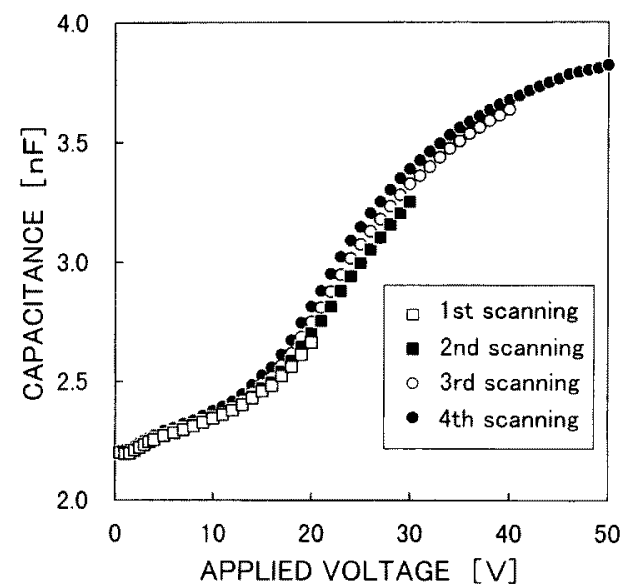

Fig. 6 Capacitance vs. applied voltage for PVA-LCPC film. Liquid crystal/monomer ratio, E-44/PVA $=60 /$ $40(\mathrm{w} / \mathrm{w})$; irradiation dose, $10 \mathrm{Mrad}$; thickness of

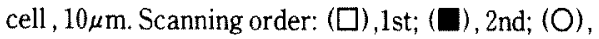
3rd; (O), 4th.

EB-LCPC膜の液晶分子は, 低い印加電圧から急激に配 向し，10Vでほぼ完了しているが，透過率は最終透過率の $60 \%$ に満なない.20Vまで徐々に配向が推むことによって， 透過率はほほ飽和した。.20VまではC れず，液晶分子の配向状態に電任印加の履歴は認められ ない. しかし, 30Vの電圧印加以降, $C_{p}$ の挙動は変化し, 履歴が発生している。ささらに高い電压を印加すると， $C_{p}$
に極小值がみられ，液晶分子の配向状態が一旦乱れてい る様子がうかがえるが，透過率は徐々に增大している。 このような現象は, EB-LCPC膜中で次のような分子的お よび構造的変化が生しているものと推測される。

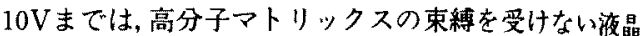
分子が，急激に配向才ることによって透過率が変化し，

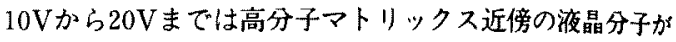
配向することによって透過率が変化したものであろう。 これは，後述するように，Drzaic[24]が本研究と同し作 製法のPVA-LCPC膜で報告した内容と対応しているか， EB-LCPC膜の場合，高分子マトリックスから束縛される 液晶分子は少なく, PVA-LCPC膜よりも低い電圧で駆動 したようである。このように，20VまではEB-LCPC膜の 構造变化は生じておらず，七ステリシスが小さいものと 考えられる。しかし，30V以上の電圧を印加すると，前節 で示したような高分子マトリックス中の液晶分子の配向 が、高分子マトリックスの構造変化を引起こし，ヒステ リシスを増大させたものと考えられる，また。このよう な構造变化による高分子マトリックス中の残存モノマー の液晶中への溶出も関与している可能性がある.

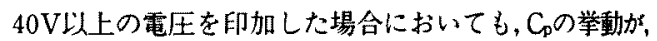
どのような構造変化に基づいているがは不明であるが, EB-LCPC膜のヒステリシスは, 液晶が溶解した高分子マ トリックスの分子運動性が高いことに基づいており，電 圧印加によって生しる高分子マトリックスの構造変化お よびそれに伴う残存モノマーの液晶への溶出に起因して いるものと推測される。

一方，PVA-LCPC膜については，低い印加電圧から最 終印加電压まで，一定の速度で配向する液晶分子の様子 がうかがえる. 低印加電圧でも，液晶分子は配向するが， 極めて稳やかで，透過率変化には反映されていない，印 加電圧が高くなるにしたがって，液晶分子の配向は徐々 に進み，15Vあたりから透過率の変化が想められる。その 後は，配向挙動に対応した透過率变化を示している，特 に重要な相違点として,EB-LCPC膜と比较して低い車圧 (20V)印加で, 既にC $\mathrm{p}$ の挙動に变化が見られ, 液晶分子の 配向挙動が電压印加の履歴を受けていることが举げられ る.

このようなPVA-LCPC膜の一連の現象は, Drzaic[24] が報告しているように，液晶分子か，液晶粒子の中央か ら高分子マトリックス近傍へと順次配向が進むことを示 しているが，高分子マトリックスに束縛されない液晶分 子と束縛される液晶分子の境界を見出すことはできなか った。しかし，透過率変化から，高分子マトリックスに 束䋠される液晶分子が予想以上に多いことが分かる。ま た，PVA-LCPC膜の高分子マトリックスは，線状高分子 
で、架檽していないためそそこに溶解した液晶分子はか なり低印加電圧から配向に寄与し, 構造変化を生してい るものと考えられる。この分子運動性の高さが, EB-LCPC 模よりもヒステリシスおよびそのV而依存性が大きい原 因であろう。

したがって，PVA-LCPC膜の場合にも，ヒステリシス の要因は，液晶を溶解した高分子マトリックスの高い分 子運動性にあり，電圧印加によって生じる構造変化が七 ステリシスをもたらしているものといえる.

このように,EB-LCPC膜には残存モノマーが存在する という違いはあるものの, LCPO膜のヒステリシスは, LCPC 膜の作製法によらない類似性がある，それは，高分子マ トリックスに溶解した液晶が、高分子マトリックスを可 塑化し，高分子マトリックスの分子運動を高めるため， 印加電压に応答する液晶が構造変化を生起することであ る。この考え方に従えば，低い印加電压の領域において， PVA-LCPC膜よりもEB-LCPC膜の方が，ヒステリシス 幅およびその電圧依存性が小さい要因は，EB-LCPC膜の 高分子マトリックスは架橋しており，分子運動性が低い ことにある。一方，高い印加電圧の領域において，EB-LCPC 膜の飽和したようにみえる透過率がさらに変化する要因 は，分子運動による構造変化が支配的であると考えられ るか，それに伴う高分子マトリックス中の残存モノマー の湾晶への溶出も関与していると推測される。

\section{4. 結 論}

LCPC膜に特有のヒステリシスは，液晶を溶解した高分 子マトリックスの分子運動性と密接に関わっており, 従 来のLCPC膜の作製方法では, 相分離の完全性, 重合の完 站性など，解決困難な本質的問題を含んでいるものと考 えられる。このため，上ステリシスの解決には，作製方 法ならびに材料を総合的に研究する必要がある.

\section{交嗝}

1. C. Hilsum, U. K. Pat. 144236 (1973).

2. H. G. Craighead, J. Cheng, and S. Hackwood, J. Appl. Phys. Lett., 48(1), 22(1982).

3. J.L. Fergason, SID Int. Symp. Dyg. Tech. Papers, 16, 68(1985).

4. J. W. Doane, N. A. Vaz, B.-G. Wu, and S. Zumer, Appl. Phys. Lett., 48(4), 269 (1986).

5. N. A. Vaz, G. W. Smith, and G. P. Montgomery, Jr., Liq. Cryst., 146, 1 (1987).

6. J. L. West, Mol. Cryst. Liq. Cryst. Inc. Nonlin. Opt., 157,427 (1988).

7. T. Kajiyama, A. Miyamoto, H. Kikuchi, and Y.
Morimura, Chem. Lett., 1989, 813.

8. 竹内清文, 高津晴義, 小川洋, 藤沢宜, 丸山和則, 第15回液晶討諭会講演予稿集，206(1989)。

9. M. Kunugida, Y. Hirai, Y, Ooi, S. Nishiyama, T. Asakawa, K. Masumo, H. Kumai, M. Yuki, and T. Gunjima, SID Int. Symp. Dig. Tech. Papers, 21, 227 (1990).

10. 熊井裕, 機能材料, 12(8), 13(1992).

11. A. Tomita, SID Int. Symp. Dig. Tech. Papers, 24, 865 (1993).

12. 高津晴義，機能材料， 13(2)，5(1993).

13. Q. Wang, R. Sun, Y. Tian, X. Huang, and I. Tsunoda, Proc. $3^{\text {rd }}$ Int.Disp. Workshops, 1, 97 (1996).

14. F. P. Nicoletta, C. Caruso, G. De Filp, G. Chi Dichimo, H.-A. Hakemi, and M. Santangelo, Proc. SPIE Int. Soc. Opt. Eng., 3319, 285(1998).

15. G. W. Smith, Mol. Cryst. Liq. Cryst., 241, 37 (1994).

16. 小泉慈，大坪泰文，甘利武司，高分子論文集， 51 , 303(1994).

17. J.-H. Liu, M.-Z. Chen, and Y.F. Wang, Angew, Makromol. Chem. 231, 109 (1995).

18. J.-H. Liu, H.-C. Liu, Y.-C. Chong, J. Appl. Polym. Sci., 61, 1747 (1996).

19. S. H. Kim, O. C. P. He, B. K. Kim, and K. S. Park, Polym. Int., 46(2), 143(1998).

20. S. Niiyama, Y. Hirai, H. Kumai, T. Wakabayashi, and T. Gunjima, SID Int. Symp. Dig. Tech. Papers, 23, 575(1992).

21. J. D. Margerum, A. M. Lackner, J. H. Erdmann, and E. Sherman, Proc. SPIE, 1455, 27 (1991).

22. Y. Yamada, T. Hirai, N. Ohnishi, S. Kouzaki, F. Funada, and K. Awane, T. Uchida, Proc. The $12^{\text {th }}$ Int. Disp. Res. Conf. (Jpn. Disp. '92), 695 (1992).

23. J. De Baets, J. Capon, A. M. De Cubber, H. De Smet, A. Van Calster, J. Vanfleteren, T. Fujisawa, H. Ogawa, M. Aizawa, H. Takatsu, The $13^{\text {th }}$ Int. Disp. Res. Conf. Proc. (Euro Display '93), 117 (1993).

24. P. S. Drzaic, Liq. Cryst., 3(11), 1543(1988).

25. Z. Lin, J. J. Sluss, T. E. Batchman, S. D. Heavin, and B. M. Fung, Mol. Cryst. Liq. Cryst., 220, 29 (1992).

26. E. Shimada and T. Uchida, Proc. The $12^{\text {th }}$ Int. Disp. Res. Conf.(Jpn.Disp.'92), 699(1992).

27. M. Ando and T. Uryu, J. Appl. Polym. Sci., 33, 1793 (1987).

28. M. Ando and T. Uryu, J. Polym. Sci., Polym. Lett. Ed., 27, 325(1989). 
29. T. Shindo and T. Uryu, Polym. J., 22, 336 (1990).

30。進藤忠文, 瓜生敏之, 高分子論文集, 47, 675(1990).

31. T. Shindo and T. Uryu, J. Polym. Sci., Polym. Chem. Ed., 30, 363 (1992).

32. N. A. Vaz, G. W. Smith, and G. P. Montgomery, Jr., Proc. SPIE, 1257, 9 (1990).

33. N. A. Vaz, G. W. Smith, and G. P. Montgomery, Jr., Mol. Cryst. Liq. Cryst., 197, 83(1991).

34. U. Maschke, X. Coqueret, and C. Loucheux, J. Appl. Polym. Sci., 56, 1547 (1995).

35. U. Maschke, X. Coqueret, and C. Loucheux, Nucl. Instrum. Methods Phys. Res. Sect. B, 105(1/4), 262 (1995)
36. U. Maschke, J.-M. Gloaguen, J.-D. Turgis, and X. Coqueret, Mol. Cryst. Liq. Cryst., 282, 407 (1996).

37. U. Maschke, N. Gogibus, A. Traisnel, and $X$. Coqueret, Liq. Cryst., 23 (3), 457 (1997).

38. U. Maschke, A. Traisnel, J.-D. Turgis, and X. Coqueret, Mol. Cryst. Liq. Cryst., 299, 371 (1997).

39. T. Shindo, H. Maeda, M. Ando, and T. Uryu, J. Appl. Polym. Sci., 65, 1675(1997).

40. Merck Liquid Crystals, Licrilite Brochure(1991).

41. 暒山千里, 電子情報通信学会技術研究報告(EID89-103), 89 (422), 15(1990).

42. 岡野光治 - 小林駿介編, 「液晶 - 基礎編」, 培風馆, p.217 (1985). 